\title{
Does Psychological Capital Drive the Effort of Marketers?
}

\author{
NGUYẼ̃N THI! MAI TRANG
}

University of Economics and Law, Vietnam National University - HCMC

\begin{tabular}{|c|c|}
\hline ARTICLE INFO & ABSTRACT \\
\hline $\begin{array}{l}\text { Article history: } \\
\text { Received: } \\
\text { Nov. 19, } 2013 \\
\text { Received in revised form } \\
\text { March 12, } 2014 \\
\text { Accepted: } \\
\text { March 31, } 2014 \\
\text { Keywords: } \\
\text { job effort, marketer, } \\
\text { psychological capital }\end{array}$ & $\begin{array}{l}\text { This study attempts to answer the question "Does psychological } \\
\text { capital drive the effort of marketers?" Using a survey data set } \\
\text { collected from } 364 \text { marketers working for various types of firms in Ho } \\
\text { Chi Minh City, we found that each component of psychological } \\
\text { capital has a direct and positive impact on job effort of marketers. } \\
\text { These findings suggest that firms could enhance the effort of } \\
\text { marketers in performing their job by establishing a human resource } \\
\text { management system focusing not only the human capital but also on } \\
\text { the psychological capital of marketers. }\end{array}$ \\
\hline
\end{tabular}




\section{INTRODUCTION}

Psychological capital is a type of human resources that can create competitive advantage for firms (Nguyen \& Nguyen, 2012). It is defined as an individual's psychological state of development (Luthans et al., 2005). Research has shown that psychological capital enhances job performance (Luthans et al., 2005; Luthans et al., 2008), and quality of work life (Nguyen \& Nguyen, 2012). However, to the best of our knowledge, little attention has been paid to the role of psychological capital in job effort of marketers, especially in transitioning markets like Vietnam.

At the marketing professional level, determining such relationships and mediators is of importance for firms. By thorough understanding of these relationships, firms are able to design appropriate personnel policies that recruit marketers with a high psychological capital, and nurture such a type of capital together with their knowledge and skills. For that reason, the purpose of this study is to investigate the role of psychological capital in the job effort of marketers.

We document the role that the components of psychological capital of marketers play in determining the effort of marketers in performing their job. Based on our results, we suggest that firms complement their performance in striving to enhance marketers' effort by recruiting marketers with a high level of psychological capital and nurturing such valuable capital. The remainder of the paper presents our literature review and hypotheses, methods, data analysis and results, discussion and implications, and limitations and directions for future research.

\section{LITERATURE REVIEW AND HYPOTHESES}

\section{a. Psychological Capital:}

Psychological capital is a state-like psychological capacity which is more specific to certain situations or tasks and tends to be more malleable over time (Chen et al., 2000). It is a multidimensional construct and is defined as "an individual's positive psychological state of development that is characterized by: (1) having confidence (selfefficacy) to take on and put in the necessary effort to succeed at challenging tasks; (2) making a positive attribution (optimism) about succeeding now and in the future; (3) persevering toward goals and, when necessary, redirecting paths to goals (hope) in order to succeed; and (4) when beset by problems and adversity, sustaining and bouncing back and even beyond (resiliency) to attain success" (Luthans et al.,2007, p. 3). 
Self-efficacy refers to "people judgments about their capability to perform particular tasks" (Parker, 1998, p. 835). At the marketing professional level, self-efficacy refers to marketers' confidence in their knowledge and skills when performing their assigned marketing tasks (Nguyen \& Nguyen, 2012). Optimism "involves enhancing and focusing on the favorable aspects of our experiences" (Schneider, 2001, p. 253). At the marketing professional level, "optimistic marketers are characterized by having positive expectations of outcomes in a changing work environment" (Nguyen \& Nguyen, 2012, p. 88). Hope is "the belief that one can find pathways to desired goals and become motivated to use those pathways" (Snyder et al., 2002, p. 257). Hope is connected to pathways, which refers to one's capability of generating workable routes to the desired goal, and agency, which relates to one's perceived capacity to use the pathways to reach the desired goal (Snyder et al., 1996; Snyder et al., 2002). At the marketing professional level, "pathways facilitate marketers to recognize the goals set by the firm and to translate those goals into their own actions to achieve the goals. Agency assists marketers in controlling their actions to achieve the desired goals and especially, in applying the requisite motivation to the best alternative pathway" (Nguyen \& Nguyen, 2012, pp. 88-89). Finally, resiliency relates to "positive adaptation in the context of significant adversity or risk" (Masten \& Reed, 2002, p. 75). At the marketing professional level, resiliency can be characterized by marketers' coping responses to both adverse and extreme positive events (Luthans et al., 2008; Nguyen \& Nguyen, 2012).

Research shows that the four components (hope, optimism, resiliency, and selfefficacy) of psychological capital of employees enhance their job performance, happiness, satisfaction, and well-being. For example, Stajkovic \& Luthans' (1998) and Legal \& Meyer's (2009) studies show that self-efficacy has a positive impact on performance. Research by Youssef \& Luthan (2007) reveals that employees' optimism underlies their performance, satisfaction and happiness, and that hope enhances employees' performance, satisfaction, happiness and retention. Resiliency also enhances employees' performance (Luthans et al., 2005), happiness, and satisfaction (Youssef \& Luthans, 2007). This study also focuses on the components of psychological capital of marketers. 


\section{b. Job Effort:}

Job effort is an important concept in organizational behavior. Some researchers believe that job effort is a component of job performance (Lusch \& Serpkenci, 1990). However, on the employee side, job effort and job performance are two different concepts. Job effort is the input of job performance and job performance is the output of job effort (Christen et al., 2006). Psychological capital of marketers contributes to their effort in performing their marketing duties because all components of psychological capital have a role in encouraging marketers to try their best in carrying out their duties.

Specifically, hope helps marketers to generate workable routes and to perceive capability to reach the desired goal. Optimism assists marketers in establishing positive expectations of outcomes in a changing working environment. Resiliency encourages marketers in coping not only with positive situations but also with adverse events. Finally, self-efficacy enforces marketers' confidence in performing their marketing tasks (Nguyen \& Nguyen, 2012). Accordingly, marketers with a higher level of psychological capital tend to put more effort on their work and are not afraid of difficulties, and they always adapt to difficult tasks. Thus,

H1. Hope has a positive impact on job effort.

H2. Optimism has a positive impact on job effort.

H3. Resiliency has a positive impact on job effort.

H4. Self-efficacy has a positive impact on job effort.

\section{METHODS}

\section{a. Procedure:}

We surveyed a convenience sample of 364 marketers working for various types of firms in HCMC. The data collected from this sample was used for validating the measures of the constructs used in the model and for testing the hypotheses. Composite reliability $\left(\rho_{c}\right)$ was used to test the reliability of the measures and confirmatory factor analysis (CFA) was employed to test the convergent validity of the measures and the discriminant validity among the constructs.

\section{b. Measurement:}

Two constructs were examined: psychological capital and job effort. Psychological capital were composed of four components, namely, hope, optimism, resiliency, and, self-efficacy. In this study, hope is state hope (Snyder et al., 2002). To measure hope, 
we used three items developed by Snyder et al., (2002). Optimism was measured by three items based on Carver \& Scheier (2002). Resiliency was measured by three items, adopted from Block \& Kremen (1996). Self-efficacy was measured by four items, borrowed from Parker (1998). Finally, job effort was measured by three items. This scale was based on the work of Christen et al. (2006) with some modification to fit the Vietnamese market.

Seven-point Likert scaling, anchored by 1 (strongly disagree) and 7 (strongly agree) was used for all items in this study. The questionnaire was initially prepared in English and then translated into Vietnamese by an academic fluent in both languages. This procedure was undertaken because English is not well understood by all marketers in this market.

\section{c. Sample Characteristics:}

The sample comprised 364 marketers in which 167 (45.9\%) were male and 197 $(54.1 \%)$ were female marketers. There were $181(49.7 \%)$ marketers working in the service industry and $183(50.3 \%)$ marketers working in the manufacturing industry. In terms of firm ownership, there were $46(12.6 \%)$ marketers working for state-owned companies, 165 (45.3\%) working for joint-stock companies, 15(4.1\%) working for jointventure companies, 96(26.4\%) working for limited proprietary companies, and 42 $(11.6 \%)$ working for private firms. In terms of firm size, there were $148(40.6 \%)$ marketers working for firms which had less than or equal to 100 employees, 85 (23.4\%) marketers working for firms which had from 100 to 300 employees and 131(36.0\%) marketers working for firms which had more than 300 employees.

\section{DATA ANALYSIS AND RESULTS}

\section{a. Measurement Validation:}

As discussed previously, CFA was used to validate the scales. The screening process shows that the data exhibited slight deviations from normality. Nonetheless, most of the univariate kurtoses and skewnesses were within the range of $[-1,1]$. Therefore, maximum likelihood estimation was used (Muthen \& Kaplan, 1985).

There were two constructs under investigation: psychological capital (second-order) and job effort (first-order). To assess the measures of these two constructs, we first assessed the CFA model of the second-order construct (psychological capital) and then, incorporated the first-order construct (job effort) into the CFA model of psychological capital to form the saturated model (final measurement model). 


\section{b. Psychological Capital:}

As presented, psychological capital comprised four components: hope; optimism; resiliency; and, self-efficacy. The CFA results indicate that the measurement model of psychological capital received an acceptable fit to the data: $\chi^{2}{ }_{[62]}=166.28(\mathrm{p}=.000)$; $\mathrm{GFI}=.936$; $\mathrm{CFI}=.935$; and, RMSEA $=.068$. In addition, all factor loadings were high $(\lambda \geq .53)$ and significant $(\mathrm{p}<.001$; Table 1$)$. These findings indicate that the scales measuring the components of PsyCap were one-dimensional and the within-method convergent validity was achieved (Steenkamp \& van Trijp, 1991).

\section{c. Saturated Model:}

The saturated model was formed by incorporating the measure of job effort into the CFA model of the components of psychological capital. The final CFA model received an acceptable fit to the data: $\chi^{2}{ }_{[94]}=245.38(\mathrm{p}=.000)$; GFI $=.923$; CFI $=.932$; and, RMSEA $=.067$. The factor loadings of all items measuring the first-order construct (job effort) were high $(\chi \geq .72)$ and significant $(\mathrm{p}<.001)$. These findings indicate that the scales measuring job effort was one-dimensional and the within-method convergent validity was achieved. The correlations between job effort and all components of psychological capital, together with their standard errors (Table 2), indicate that they were significantly different from unity, thus, supporting the construct discriminant validity (Steenkamp \& van Trijp, 1991). Note that no improper solution was found in any model: Heywood cases were absent; all error-term variances were significant; and, all standardized residuals were less than $|2.58|$. The CFA loadings of items, composite reliability $\left(\rho_{\mathrm{c}}\right)$, and average variances extracted $\left(\rho_{\mathrm{vc}}\right)$ of all scales are shown in Table 1.

Table 1: Means, Standard Deviation and Standardized CFA Loadings of Items

\begin{tabular}{cccccc}
\hline Items & M & SD & $\lambda$ & $\mathbf{t}$ \\
\hline
\end{tabular}

Psychological capital: Hope: Composite reliability $\rho_{\mathrm{c}}=.67$; average variance extracted $\rho_{\mathrm{vc}}=.41$

$\begin{array}{llll}\text { At the present time, I am energetically pursuing my goals } & 5.47 & 1.363 & 0.53\end{array}$

There are a lot of ways around any problem that I am facing now

$\begin{array}{llll}5.10 & 1.315 & 0.67 & 7.92\end{array}$

I can think many ways to reach my current goals

$5.00 \quad 1.423 \quad 0.70$

8.02

Psychological capital: Optimism: $\rho_{\mathrm{c}}=.72 ; \rho_{\mathrm{vc}}=.47$

In uncertain times, I usually expect the best

$4.91 \quad 1.529$

0.71

9.97 
I always expect things go to my way

$5.23 \quad 1.405 \quad 0.64$

9.44

Overall, I expect more good things to happen to me than bad

$\begin{array}{lll}5.10 & 1.430 & 0.70\end{array}$

Psychological capital: Resiliency: $\rho_{\mathrm{c}}=.60 ; \rho_{\mathrm{vc}}=.33$

I quickly get over and recover from being startled

$\begin{array}{llll}4.91 & 1.329 & .60 & 8.19\end{array}$

I am generous with my colleagues

$\begin{array}{llll}5.71 & 1.274 & .55 & 7.71\end{array}$

I get over my anger at someone reasonably quickly

$\begin{array}{lll}4.66 & 1.414 \quad .57\end{array}$

Psychological capital: Self-efficacy: $\rho_{c}=.87 ; \rho_{\mathrm{vc}}=.62$

I feel confident of analyzing a long-term problem to find a solution

$\begin{array}{lll}5.06 & 1.220 \quad 0.75\end{array}$

I feel confident of presenting my work area in meetings with senior management

$\begin{array}{llll}5.10 & 1.338 & 0.80 \quad 14.56\end{array}$

I feel confident of contacting people outside the company

$\begin{array}{lll}5.36 & 1.261 \quad 0.81\end{array}$

I feel confident of presenting information to a group of colleagues

$5.55 \quad 1.195 \quad 0.70$

15.92

Job effort: $\rho_{c}=.81 ; \rho_{v c}=.59$

I always try all my best to complete my task

$\begin{array}{lll}5.85 & 1.150 \quad .80\end{array}$

I am highly responsible for my task

$\begin{array}{llll}5.88 & 1.127 & .84 & 15.40\end{array}$

I am ready to work long hours to complete my task when necessary

$\begin{array}{llll}5.88 & 1.241 \quad .72 & 13.66\end{array}$

Note: M: mean; SD: standard deviation; $\lambda$ : standardized CFA factor loadings; $t$ : $t$-statistic (Unstandardized). 
Table 2: Correlations among Constructs

\begin{tabular}{lcccc}
\hline \multicolumn{1}{c}{ Correlations } & r & se & 1-r & t(1-r) \\
\hline Resiliency $\leftrightarrow$ Job effort & 0.69 & 0.038 & 0.31 & 8.10 \\
Self-efficacy $\leftrightarrow$ Job effort & 0.59 & 0.042 & 0.41 & 9.66 \\
Resiliency $\leftrightarrow$ Self-efficacy & 0.83 & 0.030 & 0.17 & 5.87 \\
Optimism $\leftrightarrow$ Self-efficacy & 0.48 & 0.046 & 0.52 & 11.34 \\
Optimism $\leftrightarrow$ Resiliency & 0.80 & 0.032 & 0.20 & 6.41 \\
Hope $\leftrightarrow$ Optimism & 0.52 & 0.045 & 0.48 & 10.68 \\
Hope $\leftrightarrow$ Job effort & 0.58 & 0.043 & 0.42 & 9.87 \\
Optimism $\leftrightarrow$ Job effort & 0.46 & 0.047 & 0.54 & 11.60 \\
Hope $\leftrightarrow$ Resiliency & 0.78 & 0.033 & 0.22 & 6.69 \\
Hope $\leftrightarrow$ Self-efficacy & 0.64 & 0.041 & 0.36 & 8.97 \\
\hline
\end{tabular}

\section{d. Hypothesis Testing:}

Hierarchical regression analysis was used to test the hypotheses. Two control variables, i.e., employee gender and age, were included in the model because these two demographics are usually considered when researching psychological aspects of humanbeings (Luthans et al., 2005). We first regressed job effort on all four components of psychological capital (hope, optimism, resiliency and self efficacy) and then, added two control variables (gender and age) into the model. Table 3 shows a summary of the tests for the two models. The results show that the three control variables did not improve Rsquare of the model (sig $\mathrm{F}$ change $>5 \%$; Table 3). Table 4 presents the regression coefficients. Note that multicollinearity was not a problem (VIF $<1.772$; Table 4) and heteroskedasticity was not present. 
Table 3: Model Summary

\begin{tabular}{|c|c|c|c|c|c|c|c|c|c|}
\hline \multirow[t]{2}{*}{ Model } & \multirow[t]{2}{*}{$\mathbf{R}$} & \multirow[t]{2}{*}{$\mathbf{R}^{2}$} & \multirow[t]{2}{*}{ Adjusted $\mathbf{R}^{2}$} & \multirow{2}{*}{$\begin{array}{c}\text { SE } \\
\text { (estimate) }\end{array}$} & \multicolumn{5}{|c|}{ Change statistics } \\
\hline & & & & & $\Delta R^{2}$ & F change & $d f 1$ & $d f 2$ & Sig F change \\
\hline 1 & $.577^{\mathrm{a}}$ & .333 & .325 & 2.493 & .333 & 44.79 & 4 & 359 & .000 \\
\hline 2 & $.586^{\mathrm{b}}$ & .344 & .333 & 2.480 & .011 & 2.960 & 2 & 357 & .053 \\
\hline
\end{tabular}

a. Predictors: (Constant), Hope, optimism, resiliency, self-efficacy

b. Predictors: (Constant), Hope, optimism, resiliency, self-efficacy, gender, age

Table 4: Regression Results

\begin{tabular}{|c|c|c|c|c|c|c|c|c|}
\hline & \multirow{2}{*}{ Predictors } & \multirow{2}{*}{ B } & \multirow{2}{*}{ SE } & \multirow{2}{*}{$\beta$} & \multirow{2}{*}{$\mathbf{t}$} & \multirow{2}{*}{$\mathbf{p}$} & \multicolumn{2}{|c|}{ Co linearity statistics } \\
\hline & & & & & & & Tolerance & VIF \\
\hline & Constant & 6.803 & .823 & & 8.26 & .000 & & \\
\hline H1 & Hope & .175 & .050 & .184 & 3.48 & .001 & .668 & 1.497 \\
\hline $\mathrm{H} 2$ & Optimism & .116 & .046 & .135 & 2.55 & .011 & .661 & 1.513 \\
\hline H3 & Resiliency & .161 & .059 & .156 & 2.72 & .007 & .564 & 1.772 \\
\hline $\mathrm{H} 4$ & Self-efficacy & .182 & .039 & .255 & 4.62 & .000 & .612 & 1.634 \\
\hline
\end{tabular}

Note: Dependent variable: Job effort

Consistent with $\mathrm{H} 1$, a positive correlation between hope and job effort was found ( $\beta$ $=.183, \mathrm{p}<.01) \mathrm{H} 2$ proposes a positive correlation between optimism and job effort. The estimated regression coefficient between optimism and job effort was significant ( $\beta$ $=.135, \mathrm{p}<.05$ ), thus $\mathrm{H} 2$ was supported. Further, $\mathrm{H} 3$ proposes that resiliency has positive impact on job effort. The regression results reveal that this hypothesis also received support from the data $(\beta=.156, \mathrm{p}<.01)$. Finally, $\mathrm{H} 4$ proposes a positive correlation between self-efficacy and job effort. This hypothesis was found supported by the data $(\beta=.255, \mathrm{p}<.001)$. The results also indicate that among the four components of psychological capital, self-efficacy had a strongest effect on job effort (Table 4).

\section{DISCUSSION, IMPLICATIONS AND CONCLUSIONS}

Realizing the role of psychological capital of marketers in their work, this study examined the impacts of the components of psychological capital on job effort of 
marketers. The results of this study offer a number of theoretical and practical implications.

Theoretically, whereas previous research focuses on the explanatory power of overall psychological capital, this study documents the effect of each component of psychological capital of marketers on job effort of employees at a professional level, i.e., marketers. Significantly positive impacts of all components of psychological capital on the job effort suggest that not only overall psychological but also each component psychological capital plays an important role in the job effort of marketers. Also, psychological capital is important for job effort not only in advanced economies (Luthans et al., 2008) but also in transitioning economies. This encourages more investigations in the area in such markets.

Regarding the practical implications, this study confirms that psychological capital is a factor that promotes job effort of marketers. Therefore, firms should pay attention to this psychological aspect of marketers. Firms should recruit qualified marketers focusing not only on their knowledge and skills in marketing but also on their psychological capital. Because psychological capital is in the form of state, not trait (Luthans et al., 2008), firms are able to design training programs which include training in psychological capital in order to nurture, develop and evaluate this type of capital. In doing so, firms will have qualified marketers to work for them.

In conclusion, employees in general and marketers in specific, have several types of capital (Nguyen and Nguyen, 2011). Research has shown that psychological capital is among the most important one (Luthans et at., 2005, 2007, 2008; Nguyen \& Nguyen, 2012). To fully exploited marketers' capabilities, firms should establish a human resource management system that focuses their psychological capital in order to enhance the effort in performing their job.

This study has a number of limitations. First, the study only investigates the role of psychological capital in job effort. Several other job factors such as job attractiveness, job commitment, etc. (Christen et al., 2006), should be explored in future research. Second, the study examines the role of psychological capital in job effort at the marketing professional level. Comparing this role of psychological capital in job effort with other business functions within firms, such as accounting, operations, and finance will enhance our understanding of the correlation between psychological capital and job effort. This is another direction for future research. Third, the focus of this study is on 
psychological capital. Future research may incorporate psychological capital and cognitive human capital, i.e., knowledge and skills of marketers (Nguyen \& Nguyen, 2011). Such a research study will give us an opportunity to compare and contrast the role of these two types capital in job performance of marketers. Finally, this study focuses on the state-like components of psychological factors of marketers. Incorporating trait-like components such as psychological hardiness (Nguyen et al., 2012), personality of marketers (Heaven, 1993) will provide further insights into the role of psychological aspects of marketers in their work. This is also an appropriate area for future research

\section{References}

Block, J. \& A. M. Kremen (1996), "IQ and ego-resiliency: conceptual and empirical connections and separateness”, Journal of Personality and Social Psychology, 70(2), 349-361.

Carver, C.S. \& M. F. Scheier (2002), “Optimism”, in Snyder, C.R. \&S. J. Lopez (Eds.), Handbook of Positive Psychology, Oxford University Press, Oxford, UK, 231-243.

Chen, G., S. M. Gully, J. A. Whiteman \& R. N. Kilcullen (2000), "Examination of Relationships among Trait-Like Individual Differences, State-Like Individual Differences, and Learning Performance", Journal of Applied Psychology, 85(6), 835-847.

Christen, M., G. Iyer \& D. Soberman (2006), "Job Satisfaction, Job Performance, and Effort: a ReExamine Using Agency Theory", Journal of Marketing, 70, 137-150.

Heaven, P. C. L. (1993), Human Values and Personality Dimensions: A Test of the Social Values Inventory, Personality and Individual Differences, 15(3), 307-312.

Legal, J. B. \& T. Meyer (2009), "Goal Priming and Self-Efficacy: Independent Contributions to Motor Performance", Perceptual and Motor Skills, 108(2), 383-391.

Lusch, R.F. \& R. R. Serpkenci (1990), "Personal Differences, Job Tension, Job Outcomes, and Store Performance: A Study of Retail Store Managers", Journal of Marketing, 54January, 85-101.

Luthans, F., B. J.Avolio, F. O. Walumbwa \& W. Li (2005), "The Psychological Capital of Chinese Workers: Exploring the Relationship with Performance", Management and Organization Review, 1(2), 249-271.

Luthans, F., S. M.Norman, B. J. Avolio \& J. B. Avey (2008), "The Mediating Role of Psychological Capital in the Supportive Organizational Climate: Employee Performance Relationship", Journal of Organizational Behavior, 29 (2), 219-238.

Luthans. F., C. M. Youssef \& B. J. Avolio (2007), Psychological Capital: Developing the Human Competitive Edge, Oxford University Press, Oxford, UK. 
Masten, A.S. \& M. -G. J. Reed (2002), "Resilience in Development”, in Snyder, C.R. \&S. J. Lopez (Eds.), Handbook of Positive Psychology, Oxford University Press, Oxford, UK, 74-88.

Muthen, B. \& D.Kaplan (1985), “A Comparison of Some Methodologies for the Factor Analysis of Non-Normal Likert Variables", British Journal of Mathematical and Statistical Psychology, 38(2), 171-189.

Nguyen, T.D. \& T. T. M.Nguyen (2011), "Firm-Specific Marketing Capital and Job Satisfaction of Marketers: Evidence from Vietnam”, Learning Organization, 18(3), 251-263.

Nguyen, T.D. \& T. T. M. Nguyen (2012), "Psychological Capital, Quality of Work Life and Quality of Life of Marketers: Evidence from Vietnam”, Journal of Micromarketing, 32(1), 82-90.

Nguyen, T. D, C. J. Shultz \& D. M. Westbrook (2012), "Psychological hardiness in learning and quality of college life of business students: Evidence from Vietnam", Journal of Happiness Studies, 13 (6), 1091-1103.

Parker, S.K. (1998), "Enhancing Role Breadth Self-Efficacy: the Roles of Job Enrichment and other Organizational Interventions", Journal of Applied Psychology, 83(6), 835-852.

Schneider, S.L. (2001), "In search of realistic optimism meaning, knowledge, and warm fuzziness", American Psychologist, 56(3), 250-263.

Snyder, C.R., K. L. Rand \& D. R. Sigmon (2002), "Hope Theory: A Member of the Positive Psychology Family”, in Snyder, C.R. \& S. J. Lopez (Eds.), Handbook of Positive Psychology, Oxford University Press, Oxford, UK, 257-276.

Snyder, C.R. et al. (1996), "Development and Validation of the State Hope Scale", Journal of Personality and Social Psychology, 70(2), 321-335.

Stajkovic, A.D. \& F.Luthans (1998), "Self-Efficacy and Work-Related Performance: A Meta Analysis", Psychological Bulletin, 124 (2), 240-261.

Steenkamp, J.-B.E.M. \& H. C. M. van Trijp (1991), “The Use of LISREL in Validating Marketing Constructs", International Journal of Research in Marketing, 8 (4), 283-299.

Youssef, C.M. \& F. Luthans (2007), "Positive Organizational Behavior in the Workplace: The Impact of Hope, Optimism, and Resiliency”, Journal of Management, 33 (5), 774-800. 